\title{
The relationship between school feeding practices and students' retention in secondary schools of Nyanza District- Rwanda
}

\section{Niyizimigambi Theogene ${ }^{1}$ and James Kant Kamuhanda ${ }^{2}$}

\author{
${ }^{1}$ School of Education, Mount Kenya University, \\ Kigali, Rwanda \\ ${ }^{2}$ School of Public health, Mount Kenya University, \\ Kigali, Rwanda
}

\begin{abstract}
To establish the relationship between school feeding practices and students retention in secondary schools of Nyanza District-Rwanda, the target population is 338 while the sample size is 184 respondents obtained using Yamane formula; including 170 students and 14 teachers of secondary public schools of Nyanza district, which have started implementing school feeding program from its start in 2015. The quantitative and qualitative reproaches were used to assess the relationship between the school feeding practices and students' retention rates in secondary schools. The researcher used descriptive research design for descriptive purposes. Purposive sampling was used to select teachers while stratified random sampling was used to select students; the proportional ratio was used for determining the respondents from each category. Data were analyzed using qualitative and quantitative techniques. Frequencies, tables, percentages, mean, charts, graphs and Karl Pearson coefficient of correlation with the use of SPSS version 22.0 was used to analyze the data obtained from the field. relationship between school feeding practices and students' retention in secondary schools, Karl Pearson coefficient of correlation was 0.814 which showed the strong positive correlation. The researcher recommended that the parents should play a major role in school feeding program; the teachers, students and the educational officials as well as the ministry
\end{abstract}

of education should enhance the strategies of school feeding activities.

Keywords:

School Feeding, Students' retention, Students, and Nyanza District

\section{Introduction}

Globally, school feeding programs among others require critical intervention that was established in various countries of the world including those with high development and others of in developing ways. This program accelerated the students' enrolment and poverty stimulation as well as stunted academic performances in their secondary schools. Akanbi (2013) as many western developed countries such as United Kingdom, United States of America, and others used the Feeding for Education to accelerate the health of students and little children (Gokah, 2008). The forms of Feeding for Education improved the program of taking food and snacks at school until these countries turned into school feeding program (SFP). The India, one of the Asian countries, in 2001 the Supreme Court has approved the governmental rules and regulations of providing cooked balanced diet meal to the selected schools of secondary levels (Afridi, 2010). The Bangladesh International Policy Research Institute has carried out a research on the utilization to school feeding within secondary schools for the objective of enhancing school feeding 
in schools where the enrolment in the country, during, that year of 2010 , increased at $14.2 \%$. This has reduced the number of dropout students by $7.5 \%$ and increased the attendance at school at $1.3 \%$. School feeding in Bangladesh has raised the number of enrolment in schools where school based students enrolment increased at $20 \%$ and a $2 \%$ decrease on those truant students (Afridi, 2010).

In Kenya one of the East African community counties where ENESCO held meeting in 1990, reported that school feeding programs have raised their education outcomes. According to the Government of Kenya there were the years of experience by running the program and the impacts of this program was distinctive to all Kenyans where it has raised the policies of education and extended the health needs of the school age children and adult benefited from joining different levels of the classes. Therefore school feeding in Kenya helped poor communities, arid and semi-arid areas (Bright Hope, 2012).

Rwanda, on $17^{\text {th }}$ August 2012, has stated the implementation of the school feeding program after a pilot in the country World Food Program center of excellence which aims at fighting against hunger has paid a visit to Rwanda for following up the study. The country of Rwanda and the delegated people made of the representatives of the center of excellence such as FNDE and ABC had agreed upon a number of proposed next steps to put in practice the government program on school feeding in schools. Currently there are three school feeding programs operating in the country, two of which is Government funded and operated programs. One is a MINAGRI funded school one cup on child program of provision of milk to the little children in all public schools in preprimary schools and lower primary levels in order to fight against malnutrition and stenting among children from vulnerable families. The other institution to initiate the program is MINEDUC which funds program that subsidizes meals cooked at secondary schools public and government aided schools, hereafter referred to as a secondary school feeding program. The third program is implemented by WFP, providing secondary and primary school students with cooked meals for lunch to secure districts and schools in sectors. The ration is the hot meal consisting with fortified maize for food, beans, vegetable oil and salt. The three programs combined respond to $10 \%$ of all students in pre-primary, primary and secondary schools in Rwanda (ESSP 2013/14-2017/18).

In the previous 7 years the State of Rwanda had adopted the EFA initiated by presenting the free education on primary (FPE) in 2003 and education for all and free to secondary school learners in 2008 (Ministry of Education, 2004). Parent Teacher Associations were also brought in to play address the issue of students' retention, through school management training and the District Fund for Education to support access to education for children from poorer backgrounds, One cup of milk per child introduced in 2010 with school feeding program for secondary schools introduced in 2015 (ESSP 2013/14-2017/18). However, despite all the above impressive progress and achievement in the education sector, school dropout rates across Nyanza District are still high (DEO, 2015) remains a challenge. Due to the fact that there is knowledge gap of school feeding practices and students' retention in Nyanza District - Rwanda, this study stands for that.

\section{Review of Literature}

Historically, school feeding program has got its origin from 1930s, when the program established in United States of America and United Kingdom which had the purpose of assisting students and encouraging them in learning and children physical and mental growth. In the early 1940s, SFP was introduced to South Africa with supplying meal to coloured and while schools with free milk (RNEHSA, 2007). In the country of Rwanda, this program of school feeding was launched in 2002 by WFP with aim to support the Rwandan Government goals to implement the education for all and universal education in primary and secondary schools 2015 (WFP, 2008). By the end of 2013, WFP was assisting eleven (11) districts of the Eastern province to relief the consequences caused by the long drought resisted in this Province. In 2014, the Government of Rwanda took decision to embark to a "Community Based National School feeding Programme" in all public schools and initiated "one cup of milk per child (inkongoro y'umwana)" programme, an idea which was implemented from January 2016. The vision was to assists the primary schools and preprimary school to get food during launch time in order to reduce dropout, and increase the performance of the school. In order to make this program successfully to the population, the use of local meal such beans, salt, vegetables, oil, maize floor and other local food should be maintained to (MINEDUC, 2015).

According to the UNICEF (2009) when a sibling has got all the requirements he/ she develops a very fruitful learning and become a blessing to the society due to that they become intelligent human to serve their communities. School feeding program has increased the micronutrient fortification which increased the hope among children to resist to the different diseases. If children get good health they become productive to the country and their families 
through their effective education and through the absence of malnutrition. Thus, there is big benefit from school feeding program to the education system (UNICEF, 2009).

In 2009, World Bank confirmed the fund permanent funds for school feeding program to the developing countries where the high and middle income countries should provide some funds in order to save the poor and vulnerable families which are not able to find food. This opinion has raised the learners' enrollment and decreased the death rate of children who were losing their lives due to the malnutrition, especially in poor communities. The comprehensive school feeding is universal in these said middle income countries and high income countries. According to the World Bank, these countries consider the school feeding as a weapon to combat malnutrition aiming at having wellbeing children who are able to join schools and develop their cognitive, psychomotor and affective domains of learning. In order to stand against global crises, World Bank has encouraged the countries to enhance school feeding programs among their countries as well as mobilizing the parents to contribute to this program so as to avoid the financial crises (World Bank, 2019).

Amed's research carried out on the program of school feeding which had significantly impacted positively on the population. The research of Ahmed showed that both net and gross school registration rate reached to $14.2 \%$ and $9.6 \%$ increases respectively. This research did not show the other treatment characteristics in the unobservable households' effects to the enrolment on school feeding program. Therefore, this program has developed the boost to inclusive education and the universal education (Ahmed, 2004).

Under food for education project, the study was carried out on 32 African Countries in Sub-Saharan where the provision of food scheme said to contribute to the increment of the total enrollment of the students in schools was distinctive to the students from vulnerable families. The assistance of schools was provided up to $28 \%$ for girls and $22 \%$ for boys in only one year (Gelli, Meir et al, 2007). The enrolment scheme has shown by World Food Program where in only $1^{\text {st }}$ year the program of Food for Education has provided food in schools as well as other food for taking home. This called onsite food offered to students for taking home has increased the attendance and the enrolment of girls up to $30 \%$ in the $1^{\text {st }}$ academic year than the previous years (Gelli, Meir et al, 2007).

The implementation of the school feeding program, as shown by the researchers on the same subjects, was exercised in the schools for the enhancement of the enrolment through school feeding program. In the country of Ethiopia the program of school feeding has help the students of primary level and secondly levels to begin their courses without taking into account of their ages because some of them were aged comparing to the school ages.in very little time according to Adelman et al. (2008) students' awareness on school enrolment has been recommended to the communities (Adelman et al., 2008).

School feeding programmes positively impact on the learning for education achievement by reducing students' absenteeism and increasing students' attendance, and enrolment and mitigating dropouts' issues. In some African countries the program of feeding at school has contributed to population incentives where those who work for this program get some payment for performing the assigned tasks at their respective schools where they work. This encourages students and their families especially girls and poor communities who benefit from this school feeding program (Powell et al., 2006).

In December 2009, World Food Program presented that there was a boy graduated from primary school in the country of Cameroon when The World Food Program was providing free daily day food to learners, he reported that from their homes they often eat little millet than at their primary schools, they get to eat rice and beans, the boy testifies that he got enough meal at school that he/she could attend and graduate from his/her studies!". The school feeding program could again provide people with the households' incentives to bring their children at school for free education and free school feeding program. The household income increases due to the fact that poor families get some extra amount of the incentives and this varies to $10 \%$ as their income average. This shows how much this program has become fruitful not only to students who enrolled in schools but also to their families (WFP, 2006).

\section{Materials and Methods}

The descriptive research design was utilized when collecting data from the characteristics of the population such as opinions, peoples' attitudes or any educational issues and social situation (Orodho $\&$ Kombo, 2002). The descriptive research design allowed the data collection from a selected sample population with flexibility and face to face communication (Borg \& Gall, 1989). This research design also helped the researcher to get the responses about the issues of teaching and learning needs the educators and the policy makers. 
According to Gall (1989) the population target related to all participants of the research for targeted population for the study. This is the population which the researcher desires to generalize research findings. This study was conducted in 8 secondary schools among 42 secondary schools located in Nyanza District, Southern Province that have been implementing school feeding program.

Table 3.1: Target Population

\begin{tabular}{llcc}
\hline No & School & Number of Teachers & Number of Students \\
\hline 1 & ES Mutima & 11 & 235 \\
2 & GS Rwanamiza & 10 & 216 \\
3 & GS Rubona & 13 & 390 \\
4 & GS Nyagasozi & 12 & 263 \\
5 & E.T. ST. Peter Igihozo & 15 & 324 \\
6 & College Du Christ-Roi Nyanza & 8 & 164 \\
7 & APADEM Busoro & 6 & 133 \\
8 & EAV Mayaga & 6 & 358 \\
& Total & 14 & $\mathbf{2 0 8 3}$ \\
\hline
\end{tabular}

Source: Nyanza District Education office, 2021.

The selected sub-group is used to collected data from, and this is called the respondent, interviewee, or informant. Thus, the sample size was calculated basing on Yamane's formula (Yamane, 1967).

$$
n=\frac{N}{1+N *(e)^{2}}
$$

Where,

$\mathrm{n}=$ the sample size,

$\mathrm{N}=$ the population size,

$\mathrm{e}=$ the accepted sampling error,

We chose Yamane's formula as it is mostly used for finite population and more simplified. The Yamen formula was used to calculate sample size with an error of $5 \%$ and confidence coefficient of $95 \%$, the researcher selected a target population of 338 from the whole population size of 2172 , through which a sample size was selected from the formula below: Using the formula of sample size calculation by Aamir Omair (2014) in his sampling methods and sample size calculation for the SAMRT methodology which demonstrates that when the researcher wants a small number of target population while the population is above 2000 , the target population is 338.

$$
=\frac{338}{1+338(0.05)^{2}}=183.19 \approx 184
$$

After finding the sample size, the researcher determined the sampling techniques of stratified random sampling and purposive random sampling.

Table 3.2: Sample size

\begin{tabular}{lccc}
\hline Respondents & Population Size & Target Population & Sample Size \\
\hline Students & 2083 & 324 & 170 \\
Teachers & 89 & 14 & 14 \\
Total & 2172 & 338 & 184 \\
\hline
\end{tabular}


Source: Primary data, 2020.

The whole target population was 338 respondents including 324 selected students who were equal to $95.8 \%$ and 14 selected teachers who were equal to
$4.2 \%$, from which a sample size of 184 was taken, and it is demonstrated as follows:

Table 3.3: Target population and Sample size according to their respective schools

\begin{tabular}{|c|c|c|c|c|c|c|}
\hline \multirow[t]{2}{*}{ No } & \multirow[b]{2}{*}{ Schools } & \multirow[b]{2}{*}{ Population } & \multirow[b]{2}{*}{$\begin{array}{l}\text { Target } \\
\text { pop }\end{array}$} & \multirow[b]{2}{*}{$\begin{array}{l}\text { Sample } \\
\text { size }\end{array}$} & \multicolumn{2}{|c|}{ Categories of respondents } \\
\hline & & & & & $\begin{array}{l}\text { Teachers' } \\
\text { Sample size }\end{array}$ & $\begin{array}{l}\text { Students' } \\
\text { Sample size }\end{array}$ \\
\hline 1 & ES Mutima & 246 & 39 & 21 & 2 & 19 \\
\hline 2 & GS Rwanamiza & 226 & 36 & 20 & 2 & 18 \\
\hline 3 & GS Rubona & 403 & 62 & 34 & 2 & 32 \\
\hline 4 & GS Nyagasozi & 275 & 43 & 23 & 2 & 21 \\
\hline 5 & E.T. ST. Peter Igihozo & 339 & 52 & 28 & 2 & 26 \\
\hline 6 & $\begin{array}{l}\text { College Du Christ-Roi } \\
\text { Nyanza }\end{array}$ & 172 & 26 & 14 & 1 & 13 \\
\hline 7 & APADEM Busoro & 139 & 22 & 12 & 1 & 11 \\
\hline 8 & EAV Mayaga & 372 & 58 & 32 & 2 & 30 \\
\hline & Total & 2172 & 338 & 184 & 14 & 170 \\
\hline
\end{tabular}

Source: Primary data, 2020.

The table 3.3 shows the target population and the sample size focusing on the respective schools where each school has provided a sample of teachers and students. Each school provided a proportional number of respondents depending on the number of population they have and they are shown in the table.

Questionnaires and interview guides were used as data collection tools. This research used research assistants in the collection of data from the respondents. This assistant was trained on how to administer the instruments. The participants were approached and appointed to carry out the task. The convenience was considered so that only days favorable to most respondents were selected. When 4. Results and Discussion

\subsection{Demographic Characteristics of the Respondents}

This section describes basic information of respondents who participated in this study; the respondents' basic information was locked at in

Table 4.1: Categories of the respondents face to face contact fails, electronic mailing and mobile phone calls were employed. The researcher distributed the instruments and collected them on the very day.

Tabulation was done as one of the most popular statistical packages which can perform highly complex data manipulation and analysis with simple instructions. Thus, the researcher used SPSS Version 22.0. Each table or figure was then followed by its interpretation. Thereafter, the relationship between two variables was analysed using Karl Pearson Coefficient of correlation and the themes of the opinions provided by the respondents during an interview guide

terms of category of respondents, gender, age group, work experience and educational level.

\subsubsection{Categories of the respondents}

During this research project, the respondents were categorised into two groups namely teachers, and students.

\begin{tabular}{lcc}
\hline Respondents & Frequencies & Percentage \\
\hline Teachers & 14 & $7.7 \%$ \\
Students & 170 & $92.3 \%$ \\
Total & $\mathbf{1 8 4}$ & $\mathbf{1 0 0 \%}$ \\
& & \\
\hline
\end{tabular}

Source: Primary data, 2021

The table 4.4 shows that the respondents were distributed into two groups; one group was composed by 14 teachers who were equal to $7.7 \%$, while the majority of the respondents were 170 
students who were equal to $92.3 \%$ of the total respondents.

Figure 4.1: Students' distribution by their respective schools

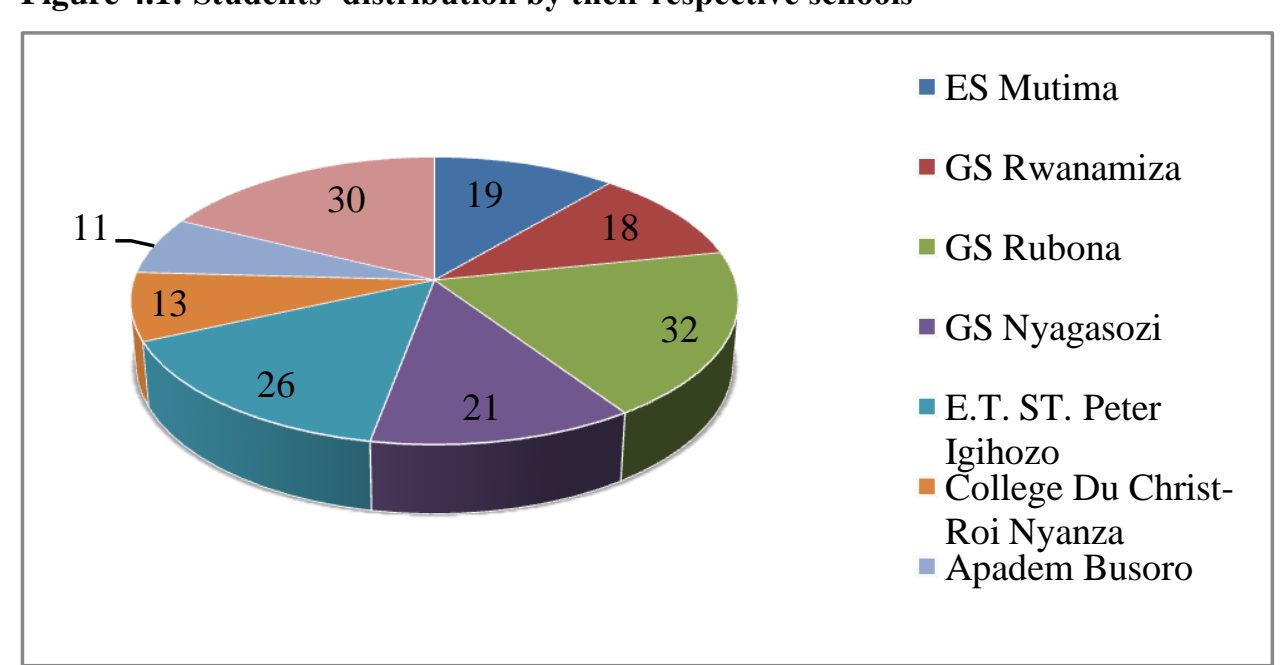
4.1.2 Students' distribution according to their
respective schools

This table show the students distributed according to their respective schools and those who managed to fill and submit their questionnaires.

Source: Primary data, 2021

As shown in the figure 4.3, the researcher distributed questionnaires to the students' respondents where the majority of these respondents were from GS Rubona with 32 students who participated in the research, 30 students were from EAV Mayaga, 26 students were from ET. ST Peter Igihozo, 21 students were from GS Nyagasozi, 19 students were from ES Mutima, 18 students were from GS Rwanamiza, 13 students were from College du Christ Roi Nyanza while the minority of 11 students were from APADEM Busoro. The students were selected depending on their numbers when the school had many students in secondary classes the number should be higher than the one with few students. So, the researcher selected the participants from senior one (S1), senior two (S2) and senior three (S3) because he could not reach all classes depending on limited time.

\subsubsection{Distribution of teachers by their respective schools}

The table 4.4 shows the informants to the side of teachers who attended in the survey and provide information on students' retention in secondary schools.

\section{Figure 4.2: Distribution of teachers by their respective schools}

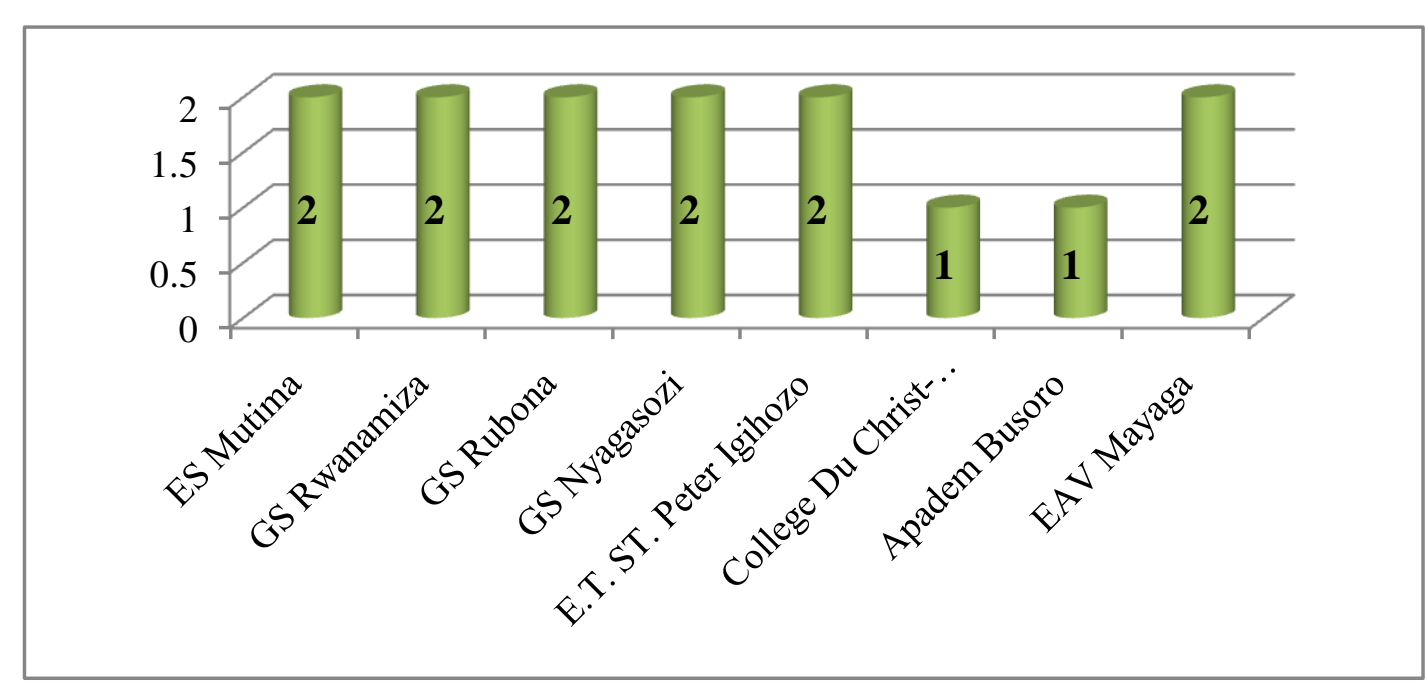

Source: Primary field data, 2021 
The figure 4.4 shows how the researcher distributed questionnaires to the teachers where they were equally selected to participate in the survey. The majority of schools provided two teachers for each including GS Rubona, EAV Mayaga, E.T. ST Peter Igihozo, GS Nyagasozi, ES Mutima, GS Rwanamiza, while among eight (8) secondary schools, only (2) schools provided one (1) teacher for each one including; College du Christ Roi Nyanza and APADEM Busoro. The teachers were selected depending on their limited number, the higher the Figure 4.3: Gender of teachers number of teachers within the school the higher the selected teachers. So, the researcher selected 7 teachers from lower secondary classes and 7 others from upper secondary classes to obtain 14 respondents to the side of teachers.

\subsubsection{Gender Distribution of teachers}

During the study, the teachers were distributed according to their gender.

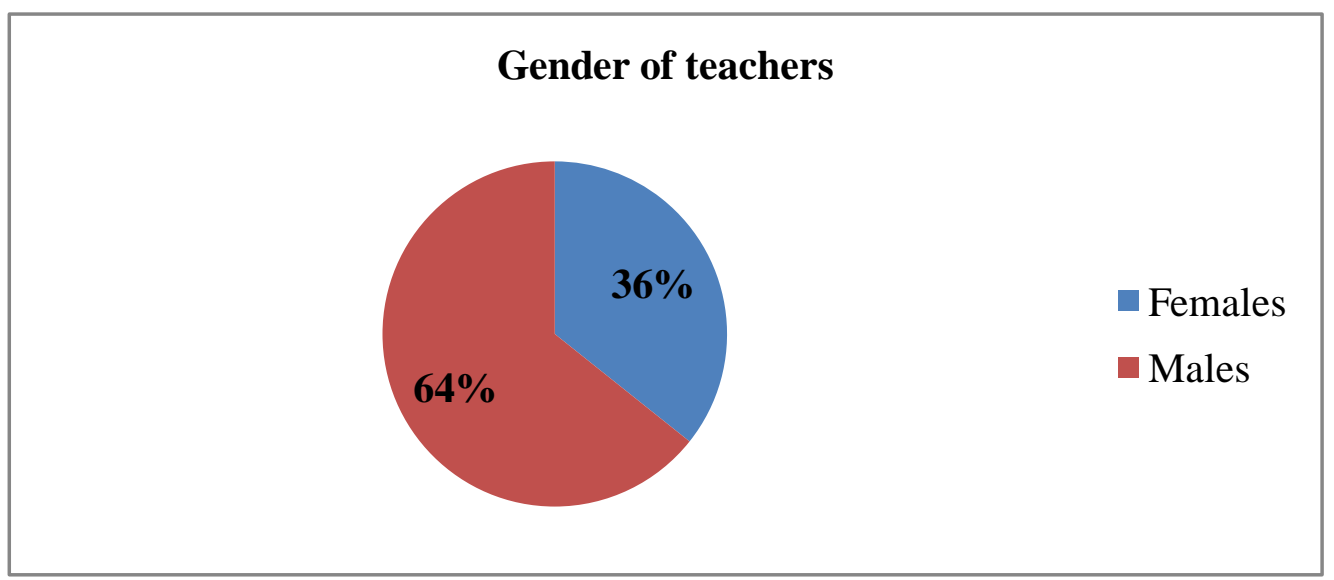

Source: Field data, 2021

The figure 4.5 shows the gender of the respondents' teachers who were present during the research; nine (9) teachers equal to $64 \%$ were males and while five (5) teachers equal to $36 \%$ were females.

\section{Teachers' age distribution}

During the study, teachers were distributed according to their age groups.

Table 4.2: teachers' age group

\begin{tabular}{lcc}
\hline Age group & Frequencies & Percent \\
\hline $\mathbf{3 0}$ or less & 1 & 7.1 \\
$\mathbf{3 1 - 3 5}$ & 3 & 21.4 \\
$\mathbf{3 6 - 4 0}$ & 5 & 35.7 \\
$\mathbf{4 1 - 4 5}$ & 3 & 21.4 \\
$\mathbf{4 6 - 5 0}$ & 0 & 0.0 \\
$\mathbf{5 1 - 5 5}$ & 2 & 14.3 \\
More than 56 & 0 & 0.0 \\
Total & 14 & 100.0 \\
\hline
\end{tabular}

Source: Primary field data, 2021

As shown in the table 4.5, the ages of teachers who participated in the study varied between in the 30 and 55. The majority of the teachers were aged between 36 and 40 and were equal to $35.7 \%$. $21.4 \%$ were aged between 31 and 35 , other $21.4 \%$ were aged between 41 and 45, 14\% were aged between 51 and 55 years old. While the minority was only one teacher who was aged to 30 years old. No one was aged between 46 and 50 or more than 56 years old. This means that the teachers were mature enough to provide information related to their career.

\subsubsection{School feeding practices employed in secondary schools}

The first objective was examining the school feeding practices employed in secondary schools of Nyanza 
District-Rwanda. The selected respondents' teachers and students of Nyanza District schools stated their understanding on school feeding practices aiming at increasing students' retention in secondary schools.

Table 4.4: Teachers' responses on school feeding practices employed in secondary

\begin{tabular}{|c|c|c|c|c|c|c|c|c|c|c|}
\hline \multirow[t]{2}{*}{ Statements } & \multicolumn{2}{|c|}{$\begin{array}{l}\text { Strongly } \\
\text { Disagree }\end{array}$} & \multicolumn{2}{|c|}{ Disagree } & \multicolumn{2}{|c|}{ Neutral } & \multicolumn{2}{|c|}{ Agree } & \multicolumn{2}{|c|}{$\begin{array}{l}\text { Strongly } \\
\text { Agree }\end{array}$} \\
\hline & Freq & $\%$ & Freq & $\%$ & Freq & $\%$ & Freq & $\%$ & Freq & $\%$ \\
\hline $\begin{array}{l}\text { The school provides cooked } \\
\text { meal regularly }\end{array}$ & 0 & 0 & 1 & 7.1 & 2 & 14.2 & 7 & 50 & 4 & 28.5 \\
\hline $\begin{array}{l}\text { The school provides } \\
\text { balanced diet }\end{array}$ & 2 & 14.2 & 3 & 21.4 & 2 & 14.2 & 4 & 28.5 & 3 & 21.4 \\
\hline $\begin{array}{l}\text { The accommodated kitchen } \\
\text { that functions }\end{array}$ & 0 & 0 & 1 & 7.1 & 0 & 0 & 8 & 57.1 & 5 & 35.7 \\
\hline $\begin{array}{l}\text { Students are served meal } \\
\text { promptly }\end{array}$ & 0 & 0 & 0 & 0 & 0 & 0 & 5 & 35.7 & 9 & 64.3 \\
\hline $\begin{array}{l}\text { All parents participate in } \\
\text { school feeding activities }\end{array}$ & 2 & 14.2 & 4 & 28.5 & 0 & 0 & 7 & 50 & 1 & 7.1 \\
\hline $\begin{array}{l}\text { Educated parents participate } \\
\text { school feeding }\end{array}$ & 0 & 0 & 2 & 14.2 & 1 & 7.1 & 5 & 35.7 & 6 & 42.8 \\
\hline Mean & 0.6 & 4.7 & 1.8 & 13.1 & 0.8 & 6.1 & 6 & 42.8 & 4.7 & 33.3 \\
\hline
\end{tabular}

Source: Primary field data, 2021

As shown in the table 4.10, the study examined school feeding practices employed in the secondary schools. As to whether the school provides cooked meal regularly, $28 \%$ of teachers strongly agreed with the statement, $50 \%$ agreed, $14.2 \%$ were neutral, $7.1 \%$ disagreed while none strongly disagreed with the statement. As to whether the school provides balanced diet, $21.4 \%$ of teachers strongly agreed with the statement, $28.5 \%$ agreed, $14.2 \%$ were neutral, $21.4 \%$ disagreed while only $14.2 \%$ strongly disagreed with the statement. As to whether the school has accommodated kitchen that well functioned, $35.7 \%$ of teachers strongly agreed with the statement, $57.1 \%$ agreed, $0 \%$ were neutral, $7.1 \%$ disagreed while none strongly disagreed with the statement. As to whether the Students are served meal promptly, $64.3 \%$ of teachers strongly agreed with the statement, $35.7 \%$ agreed, no one were neutral, nor disagreed nor strongly disagreed with the statement. As to whether all parents participate in school feeding activities, $7.1 \%$ of teachers strongly agreed with the statement, $50 \%$ agreed, $0 \%$ were neutral, $28.5 \%$ disagreed while only $14.2 \%$ strongly disagreed with the statement. As to whether are the educated parents who contribute to school feeding, $42.8 \%$ of teachers strongly agreed with the statement, $35.7 \%$ agreed, $7.1 \%$ were neutral, $14.2 \%$ disagreed while none strongly disagreed with the statement. As shown in the mean, the total of $76.1 \%$ is in the agreement position that the cited practices influence school feeding programs.

\subsubsection{The relationship between school feeding practices and students retention}

The researcher, in the third objective, discovered the relationship between school feeding practices and students retention in secondary schools of Nyanza District using Karl Person coefficient of correlation as follows:

Table 4.4: The relationship between school feeding practices and students' retention

\begin{tabular}{llcc}
\hline Variables & & Students' retention & School feeding practices \\
\hline \multirow{2}{*}{ Students' retention } & Pearson Correlation & 1 & 0.814 \\
& Significance. (2-tailed) & & 0.02 \\
& $\mathrm{~N}$ & 184 & 184 \\
& Pearson Correlation & 0.814 & 1 \\
School feeding practices & Sig. (2-tailed) & 0.02 & 184 \\
\hline
\end{tabular}

Correlation is significant at the 0.02 level (2-tailed). 
As the table 4.16 shows, the findings to the third objective from all respondents' teachers and students which were to ascertain the relationship between school feeding practices and students' retention in secondary schools in Nyanza District-Rwanda. If Pvalue is less than 0.05 then it is significant. Therefore, it was found that P-value was 0.02 and it is interpreted that school feeding practices was significant to students' retention in secondary schools.

When Karl Pearson coefficient of correlation (r) lies between 0 and 0.5 there is a low positive correlation, when it lies between 0.5 and 1 there is high positive correlation between two variables (independent variables and dependent variable). Thus, it found that Karl Pearson correlation between school feeding practices and students' retention in secondary public schools of Rwanda was 0.814 ; which means that school feeding practices on students' retention was significant.

In terms of the relationship between school feeding practices and students retention in secondary schools. The researcher managed to record the following views where during an interview guide with teachers of the selected secondary schools of Nyanza District, the respondents' views were analyzed and presented: Theme 1: the exercises teachers practice to make school feeding productive to their secondary students' academic retention and the how they engage parents to contribute more in school feeding program;

Teacher 1 expressed: Parents and students mobilization to be involvement in school feeding activities depending of their ubudehe categories, those who are in first categories of social class (ubudehe) they do not pay anything, instead, they look for school materials or other stakeholders are engaged in school feeding funds because there students who are funded by some national and international humanitarian organizations.

Theme 2: Description of the image to the effects of school feeding practices on secondary students' retention;

Teacher 2 expressed: The effects of school feeding practices to our secondary students are that all students get equal chance and right to education. Not only that, this program of providing meal to secondary students increased the attendance in schools where students are no longer absent nor late at school, it decreased the school dropout rate where those who dropped out of the school due to the hunger, decreased. This raised the number of students' promotion at over $90 \%$.

\section{Conclusions}

This confirmed by $33.3 \%$ of the teachers who responded; strongly agree, $42.8 \%$ of teachers who responded; agree, $6.1 \%$ of teachers were neutral, only $13.1 \%$ of teachers responded disagree while $4.7 \%$ responded strongly disagree. This was also confirmed by $30 \%$ of the students who responded; strongly agree, $39.9 \%$ who responded; agree, $8.6 \%$ were neutral, $14 \%$ responded disagree while only $10.5 \%$ responded strongly disagree. If the total mean of teachers who are equal to $76.1 \%$, the students who are equal to $69.9 \%$; this shows that the listed school feeding practices played a major role in students' retention in secondary schools. As to whether there is a relationship between school feeding practices and students' retention in secondary schools, Karl Pearson coefficient of correlation was 0.814 ; this shows that there was a strong positive correlation

\section{Acknowledgments}

I wish to acknowledge Dr. James Kant Kamuhanda for his contribution to this work from the beginning up to it's the completion. I need to extend my acknowledgement to the Mount Kenya University, Bank of Kigali authorities for their support and collaborative in term of data collection

\section{Reference}

[1] Adelman, S., Daniel O Gilligan and Kim L. (2008).Impact of alternative Food for Education Programmes on Child Nutrition in Northern Uganda. Washington, DC: International Food Policy Research Institute.

[2] Ahmed AU. (2004). The impact of feeding children in Schools: Evidence from Bangladesh. Washington, DC: International Food Policy Research Institute.

[3] Ahmed, AU and Billah, K. (1994). Food for Education Program in Bangladesh: An Early Assessment. International Food Policy Research Institute, Bangladesh Food Policy Project, Dhaka.

[4] Akanbi G.O. (2013). Home Grown School Feeding and Health Programme in Nigeria: An Innovative Approach to Boosting Enrolment in Public Primary Schools - A Study of Osun State, 2002-2010. African Symposium, 11(2), 8-12.

[5] Bleichrodt, N. and Born, M.P. (1996). Iodine Deficiency Disorders: A metaanalysis. International Journal of Psychology p.5768-5768 
[6] Bundy, D., Burbano, M., Grosh, C., Gelli, M., Jukes, A., \& Drake, L. (2009). Rethinking school feeding: Social safety nets, child development and the education sector. Washington, DC: World Food Programme and the World Bank.

[7] Child in Local Development. (2008). Planning Manual (2 ${ }^{\text {nd }}$ ed.). CHILD: Addis Ababa

[8] Gall D., Meredith J., P. Gall and Walter R. B. (1989).Educational Research : An introduction (5th. Ed).New York: Longman.

[9] Grosh, M., delNinno, C., Tesliuo, E. and Ouerghi, A. (2008) For Protection and Promotion: The design and implementation of Safety Nets. World Bank, Washington D.C

[10]King, M. (1966). Medical Care in Developing Countries. London Oxford University Press, London.

[11] Kothari, C.R. (2004). Research Methodology, Methods and Techniques. $\left(2^{\text {nd }}\right.$ ed..). New Age International Ltd Publishers.

[12] Kristjansson, E.A., V. Robinson, M. Petticrew, B. MacDonald, J. Krasevec, L. Janzen, T. Greenhalgh, G. Wells, J. Mac Gowan, A. Farmer, B.J. Shea, A. Mayhew and P. Tugwell .(2007). School Feeding for Improving the Physical and Psychosocial Health of Disadvantaged Elementary School Children. Copenhagen.

[13] Kruger and Badenhorst C.J, (1994). The Effects Of An Iron Fortification In A School Feeding Scheme And Anthelminthic Therapy On The Iron Status And Growth Of 6-8 Year Old School Children. University of Nairobi.

[14] Levinger, G. B., J.J. Mcleod and J.C. McLeod, (2002).Ensuring Quality Services and Sustainable Benefits through Welldesigned Exit Strategies. Journal of Feeding for Education Development, 8 (13): 128-131.

[15] Maslow, A. (1943). A theory of human motivation. Psychological Review. Retrieved April $\quad 1^{\text {st }}, \quad 2017, \quad$ from http://psychclassics.yorku.ca/Maslow/motivat ion.htm.

[16] Ministry of Education (2015). Ministry of Education Statistics Yearbook. MINEDUC: Kigali-Rwanda.

[17] Mitchell, A., Mendez Lindas S Adair (1999). Early Growth Stunting Impacts Children Cognitive Development Later In Life .Toronto.
[18] Oniango, R.K.(1990). An evaluation of Preschool feeding and Health Programs in Kenya. Research Report. Nairobi: Kenyatta University.

[19] Orodho, A. and Kombo, D. (2002). Research Methods. Nairobi: Kenyatta University Institute of Open Learning.

[20] Orodho, J.A. (2009). Elements of Education and Social Sciences Research Methods .Maseno, Kenya: Kanezja publishers.

[21] Oyefade S.A. (2014). Administration of Home Grown School Feeding \& Health Programme in Osun State. Unpublished MPA Long essay, Department of Public Administration, Faculty of Administration, Obafemi Awolowo University, Ile-Ife.

[22] Pollit, E, Jacoby, E.R, Cuerto S. (1994). School Breakfast and cognition among nutritionally at Risk Children in the Peruvian Andes. University Of California. California.

[23] Powell, C.A., S.P. Walker, S.E. Chang and Gregor, S.M. (2006).School Feeding and Education.A Randomized Trial of the Effects of School Feeding in Rural Primary School Children. Journal of the American Clinical Nutrition, 68: 873-879.

[24] Regional Network for Equity in Health in Southern Africa (2007).RNEHSA working paper, RNEHSA: Durban.

[25] Simeon D T.(1998). School feeding in Jamaica: a review of its evaluation. Am J ClinNutr.

[26] United Nations Organization. (2005). UN Millennium Project. Halving Hunger: It can be done; Summary version of the report of the Task Force on Hunger. UNO: New York.

[27] World Food Programme. (2006a). Food for Education, Experts' Seminar: Reviewing the Evidence. WFP: Rome.

[28] World Food Programme. (2007a). Thematic Evaluation of School Feeding in Emergency Situation. WFP: Rome.

[29] World Food Programme. (2008). Standardized School Feeding Survey, Country Status Report.WFP: Addis Ababa.

[30] World Food Programme.(2010). The state of food insecurity in the World. Addressing Food Insecurity in Protracted Crises. WFP: Rome.

[31] World Food Programme. (2007). The Costs and Outcomes of Fortified Biscuit Interventions on Primary School-age Children. WFP: Rome. 